\title{
Safe pediatric surgery: development and validation of preoperative interventions checklist ${ }^{1}$
}

\author{
Maria Paula de Oliveira Pires ${ }^{2}$ \\ Mavilde da Luz Gonçalves Pedreira ${ }^{3}$ \\ Maria Angélica Sorgini Peterlini ${ }^{4}$
}

Objectives: this study was aimed at developing and validating a checklist of preoperative pediatric interventions related to the safety of surgical patients. Method: methodological study concerning the construction and validation of an instrument with safe preoperative care indicators. The checklist was subject to validation through the Delphi technique, establishing a consensus level of $80 \%$. Results: five professional specialists in the area conducted the validation and a consensus on the content and the construct was reached after two applications of the Delphi technique. Conclusion: the "Safe Pediatric Surgery Checklist", simulating the preoperative trajectory of children, is an instrument capable of contributing to the preparation and promotion of safe surgery, as it identifies the presence or absence of measures required to promote patient safety.

Descriptors: Patient Safety; Pediatric Nursing; Preoperative Care.

\footnotetext{
${ }^{1}$ Paper extracted from master's thesis "Cirurgia Segura em Pediatra: Elaboração e Validação de Checklist de Intervenções Pré-operatórias", presented to Escola Paulista de Enfermagem, Universidade Federal de São Paulo, São Paulo, SP, Brazil. Supported by Conselho Nacional de Desenvolvimento Científico e Tecnológico (CNPq), process \# 476088/2010-0.

2 Master's student, Escola Paulista de Enfermagem, Universidade Federal de São Paulo, São Paulo, SP, Brazil.

${ }^{3} \mathrm{PhD}$, Associate Professor, Escola Paulista de Enfermagem, Universidade Federal de São Paulo, São Paulo, SP, Brazil.

${ }^{4}$ PhD, Adjunct Professor, Escola Paulista de Enfermagem, Universidade Federal de São Paulo, São Paulo, SP, Brazil.
} 


\section{Introduction}

Patient safety is defined as the absence of harm or accidental injury during the provision of healthcare ${ }^{(1-2)}$. In recent years, the number of studies about this topic has increased, showing high rates of errors in the healthcare field, and causing reflection and discussion for the implementation of changes in this situation worldwide.

Since human error is inevitable, particularly under complex and stressful conditions, areas such as aviation, where safety and precision are essential for an accurate provision of services, use relatively simple tools to ensure that all stages of a process are performed and, consequently, that faults are avoided. Tools like checklists are considered key elements for reducing errors ${ }^{(3-4)}$

In June 2008, the World Health Organization (WHO) published the Surgical Safety Checklist, an instrument developed from the reviews of evidence-based practices, which identified the most common causes of harm to patients in the perioperative period(4-5). In the checklist proposed by the WHO, it can be noted that the implementation procedures are limited to the operating room ${ }^{(5)}$. However, there is a consensus in relation to the importance of the preoperative period for the success of the procedure and safety of patients.

The pediatric population can be characterized as vulnerable to adverse events in the healthcare area. Children's hospitalization causes an anxiety that can change their behavior due to stress and fear. In some situations, like when subject to surgery, these reactions are enhanced, similarly to what happens with adults(6).

One way of minimizing stress and a resource used by nurses when preparing for the intervention is to provide children with information in a playful manner. Therefore, playing and listening to music help professionals to get closer to the children, improving their interaction ${ }^{(6-7)}$.

In addition, when patients and families are involved in their own safety, they are able to participate in strategies to prevent errors and, therefore, to improve their safety ${ }^{(8)}$. The information should be available to children and families, and the healthcare professionals should ensure that they are given all the information sought about the surgery, making this a challenge to the healthcare area(4,9-10).

Given that the nurses, families and children are involved in the surgery preparation process, this research is aimed at developing and validating a checklist of preoperative interventions related to patient safety, which should be completed by the children and their families.

\section{Material and Method}

Methodological study aimed at developing and validating the context and construct of an instrument used in situations where children are undergoing surgical interventions.

The research took place in a pediatric surgery unit of a university hospital in the city of Sao Paulo. The sample age group for the use of the checklist was limited to the range from preschoolers to teenagers, from their admission to hospital until their transfer to the operating room. To select the age group, the cognitive development of the children, as well as their readiness to read and paint were taken into consideration, so that they would be able to partially or fully complete the checklist. Based on the assumption of family-centered care, the checklist can be used by families as a guide for the preoperative care required for the children.

Before it was carried out, the study received approval from the Research Ethics Committee at the Institution (number 2114/11).

The checklist was submitted to content and construct validation using the Delphi technique, between March and June 2012, involving five experts in the area, amongst them a nurse specialized in pediatric surgery, a nurse specialized in patient safety, a nurse specialized in quality, a clinical pediatrician and a pediatric surgeon. The selection criteria for the judges were: to be a nurse or a physician with experience in pediatrics or patient safety for more than five years and to have completed a post-graduate degree in the area. The invitation to participate in the research was sent by email, with the guidelines and reasons for the present study, together with the informed consent form, the validation instrument and the checklist. After their acceptance, the instrument analysis process was started.

\section{The development of the checklist}

A search for information on the surgical interventions performed in children and the indicators of safe postoperative care was conducted with the medical and nursing staff of the unit. Afterwards, a literature review about the topic was performed, using national and international databases about the most important pediatric postoperative care, adverse events, 
children safety and the use of checklists for surgical patient safety.

Then, the checklist was structured and arranged into a folder format, using PagePlus Starter Edition ${ }^{\circledR}$ software. The graphic design was divided in: cover (with guidelines for completing the folder, children identification and interventions related to the children's admission), title page (with a space for families to write notes and/or comments), internal part (with the sequence of interventions to be performed with the children during the preoperative period) and back page (with a space for additional information to be provided by families).

The checklist content included drawings and child language, simulating a trajectory for the children to follow from their admission to hospital until their transfer to the operating room. The instrument was composed of 12 "steps" to be checked, regarding the care to be provided to the children during this period. A circular space was associated to each step for the children to complete with an " $X$ " or paint these gaps, as the interventions were being performed.

\section{Content and construct validation}

The validity criterion is related to the ability of the instrument to actually measure what it proposes to and, without this attention, the measures taken will not be reliable and significant ${ }^{(11-12)}$. Content validity can be assessed by different methods, with emphasis on the Delphi technique used in this study.

The Delphi technique can be defined as a group process technique which is aimed at reaching a consensus of ideas in a group of specialists about a certain topic of their expertise, through structured data collection methods, applied several times until the expected goal is achieved(12-13). The researcher should establish a consensus level in advance; in the literature, there are levels of consensus ranging from $50 \%$ to $80 \%{ }^{(13)}$. In this research, the level established was $80 \%$.

In order to use this technique, the specialists were asked to express their opinion in relation to each proposed item. The choices were: disagree, have no opinion, and agree. In the validation instrument, the semantic concordance, presentation sequence, removal, addition or change of each item was questioned. It is important to note that the combination of open questions was part of the process of acquiring information about the relevance of the instrument and its contents.

The validation instrument was composed of 15 components, being 12 "steps' and three items related to the title, guidelines in relation to the completion and notes from the families. In the first application of the Delphi technique, there was one item with a consensus level under $80 \%$, and this was submitted to a second application.

\section{Results}

Tables 1 and 2 display the results related to the validation of the checklist containing preoperative interventions related to patient safety, to be completed by the children and families. In Table 1 , the results of the first application of the Delphi technique can be seen with 15 safety indicators, of which 10 (66.7\%) have $100 \%$ consensus, $4(26.6 \%)$ have $80 \%$ and $1(6.7 \%)$ have $60 \%$ consensus. Table 2 shows the results of the second stage of the validation, which contains only one indicator that had not been previously validated and which further showed $80 \%$ consensus among the participants.

Figure 1 below relates to the presentation of the final checklist, which was given the title "The path to my surgery".

Table 1 - Application of the Delphi technique in the First Stage - Sao Paulo, 2012*

\begin{tabular}{lccc}
\hline \multicolumn{1}{c}{ Indicators } & Agreement & $\begin{array}{c}\text { Agreement to } \\
\text { maintain the step }\end{array}$ & $\begin{array}{c}\text { Agreement to } \\
\text { maintain the step } \\
\text { in that order }\end{array}$ \\
\hline Title: O caminho para minha cirurgia & $100.0 \%$ & $100.0 \%$ & $100.0 \%$ \\
Preencha os quadradinhos abaixo com "X" ou pinte-os conforme os passos & $100.0 \%$ & $100.0 \%$ & $100.0 \%$ \\
forem sendo realizados & $100.0 \%$ & $100.0 \%$ & $100.0 \%$ \\
Meu nome é & $100.0 \%$ & $100.0 \%$ & $100.0 \%$ \\
Cheguei ao Hospital Data: _-_- & $100.0 \%$ & $100.0 \%$ & $100.0 \%$
\end{tabular}


Table 1 - (continuation)

\begin{tabular}{|c|c|c|c|}
\hline Indicators & Agreement & $\begin{array}{l}\text { Agreement to } \\
\text { maintain the step }\end{array}$ & $\begin{array}{l}\text { Agreement to } \\
\text { maintain the step } \\
\text { in that order }\end{array}$ \\
\hline A enfermeira me explicou o que ocorrerá comigo aqui no hospital & $100.0 \%$ & $100.0 \%$ & $100.0 \%$ \\
\hline A enfermeira me perguntou se tenho ou não alergias & $100.0 \%$ & $100.0 \%$ & $100.0 \%$ \\
\hline A enfermeira me falou que eu não posso comer nem beber nada & $80.0 \%$ & $100.0 \%$ & $100.0 \%$ \\
\hline Hoje é o dia da minha cirurgia & $100.0 \%$ & $100.0 \%$ & $100.0 \%$ \\
\hline A enfermeira me perguntou se tenho ou não dente mole & $80.0 \%$ & $100.0 \%$ & $80.0 \%$ \\
\hline Me pediram para tirar brincos/anéis/piercing/aparelhos & $80.0 \%$ & $100.0 \%$ & $100.0 \%$ \\
\hline Tomei banho & $100.0 \%$ & $100.0 \%$ & $100.0 \%$ \\
\hline Meu médico mostrou para mim e minha família onde será feita a cirurgia & $80.0 \%$ & $100.0 \%$ & $100.0 \%$ \\
\hline Estou indo para a cirurgia daqui a pouco & $60.0 \%$ & $60.0 \%$ & $60.0 \%$ \\
\hline Observações da família & $100.0 \%$ & $100.0 \%$ & $100.0 \%$ \\
\hline
\end{tabular}

*Relative frequency

Table 2 - Application of the Delphi technique on the Second Stage - Sao Paulo, 2012*

\begin{tabular}{|c|c|c|c|}
\hline Indicators & Agreement & $\begin{array}{l}\text { Agreement to } \\
\text { maintain the step }\end{array}$ & $\begin{array}{l}\text { Agreement to } \\
\text { maintain the step } \\
\text { in that order }\end{array}$ \\
\hline Tchau! Estou indo para a cirurgia daqui a pouco! & $80.0 \%$ & $80.0 \%$ & $80.0 \%$ \\
\hline
\end{tabular}

*Relative frequency

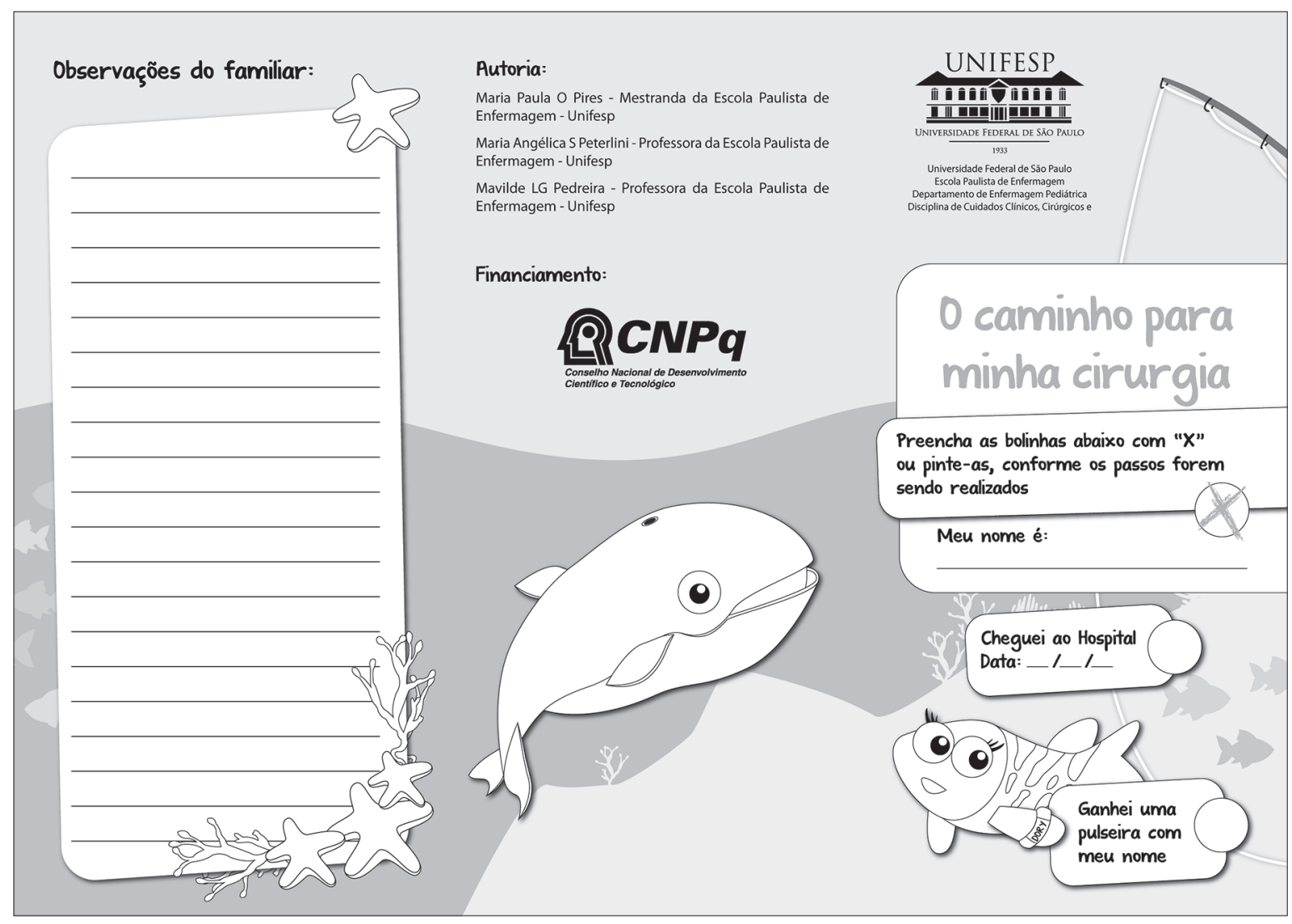

(The Figure 1 continue in the next page...) 


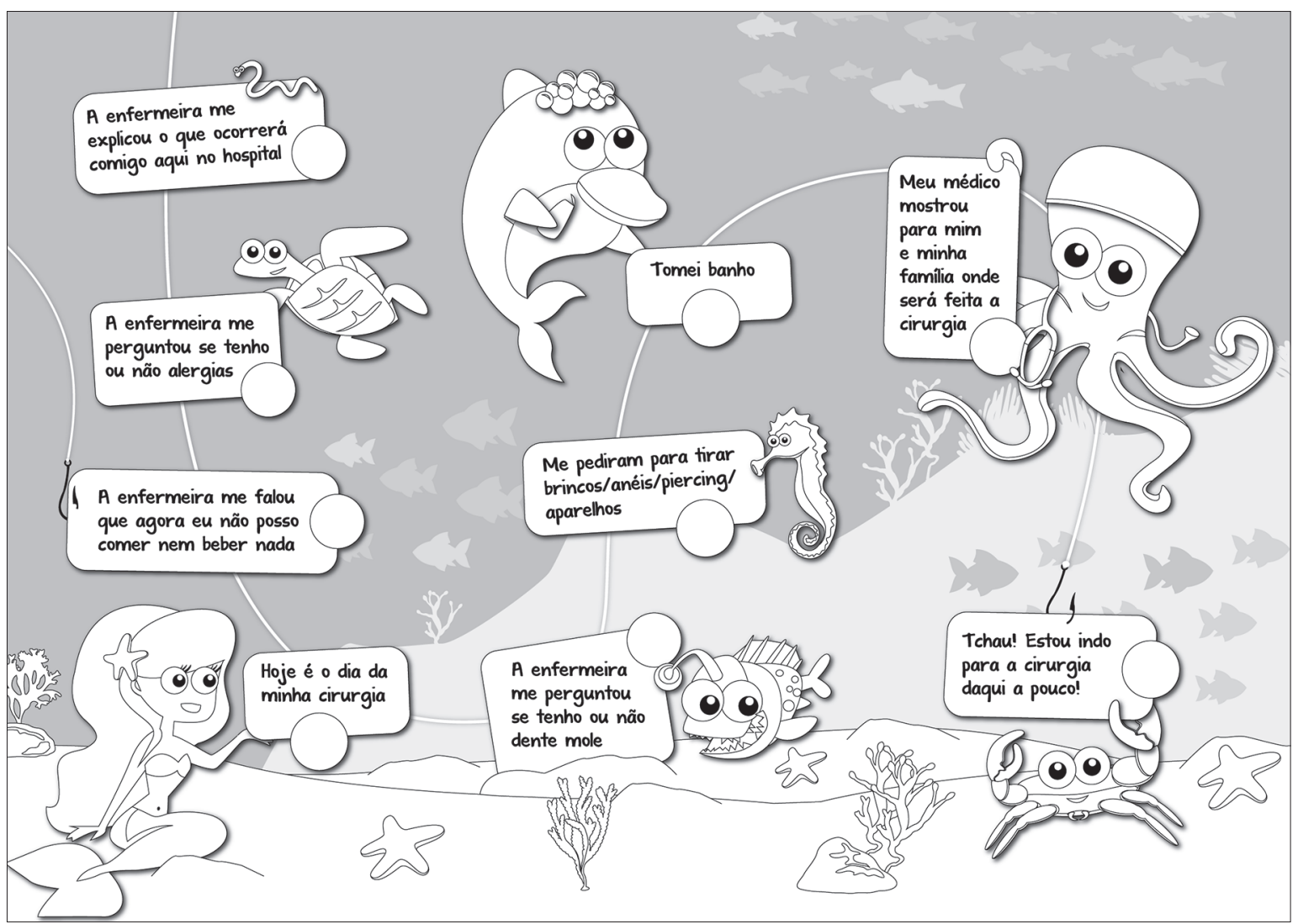

Figure 1 - Pediatric Checklist for Safe Surgery

\section{Discussion}

In the units where patient safety measures prevail, errors are seen as part of an extended process that considers the staff, the institution, the patients and the family members as co-responsible for restructuring a new risk management system ${ }^{(14-16)}$.

In 2004, the WHO established the Global Alliance for Patient Safety to promote the development of patient safety practices and policies. Then, international goals were established in 2006, such as correct identification of patients, effective communication, safety for risky medication, reduction in the risk of infections, reduction in the risk of injuries caused by falls, and particularly the reduction in the surgeries performed in wrong patients or sites ${ }^{(14)}$.

To achieve the safety goals in relation to surgical procedures, in 2008, WHO developed a checklist called "Safe surgery saves lives", which addresses the control, processes and measures taken in the operating room (before using anesthetics, before starting the surgery and after the procedure, and before the patient leaves the operating room), but the importance of preoperative preparation for the safety of patients undergoing surgery needs to be highlighted. Based on this, the researchers of this study were motivated to develop an instrument to complement the checklist proposed by the WHO, with focus on the care to children in the preoperative period and also able to cover other variables related to patient safety.

The promotion of a culture based on patient safety during hospitalization of children was the basis for the idea that the presence of a support person during hospitalization can significantly contribute to the achievement of outcomes that are capable of promoting higher quality of care, because informed patients and family members may actively promote their own safety. Gaps were identified concerning failures in the communication between healthcare professionals, children and family members, with emphasis on communication problems with family members, the use of technical terminologies, the lack of information on medical records, the reaction of the professionals to the inquiries of children or their families, and the provision of hidden or incomplete information ${ }^{(17-19)}$.

From the perspective of the support people, a safe and quality care to hospitalized children includes the intentions of the healthcare team in conjunction 
with effective communication, as well as a quality and accurate individual care, the sanitation of hands and work tools, sensible professionals with a critical view, and also the access to and understanding of the information related to the children ${ }^{(17)}$.

The division of basic hygiene care, comfort and feeding of children with the support people during their hospitalization is a measure desired by mothers, provided they are supervised by the nursing professionals and do not exclude or replace the work of the team. Thus, they can promote the involvement and participation in their children's care, improving the communication process with the professionals, and also preserving their ability to observe and offer protection and support to the children ${ }^{(17)}$.

Based on this aspect, the choice of items which constitute the developed instrument is related to the premise of promoting greater assertiveness in the safety measures during this period and chances of double checking by patients and healthcare professionals, concerning certain measures that can contribute to the safety, turning the children and family members into active agents in the promotion of measures that increase the safety of the procedures, being able to understand and participate in the provision of care.

The choice of items related to the safety of children undergoing surgery was based on the experience of healthcare professionals, researchers and on the national and international literature. Specialists in the subject also participated in the development the instrument.

Since the beginning, it was believed that the most appropriate way of promoting the participation of children would be through the use of language appropriate to the age group and a playful manner.

An instrument like the checklist consists of a list of measures or criteria, systematically organized, which allows users to register the presence or absence of each item described, so as to ensure that all aspects of that measure were addressed or completed. It emphasizes essential criteria that need to be considered in a specific $\operatorname{activity}^{(4)}$.

The effectiveness of the checklist in the healthcare field has been demonstrated in specific and highly complex areas, such as anesthesiology, trauma and intensive care. Despite the proven benefits, its integration into clinical practice in the Brazilian healthcare field is still not as fast and wide as with other fields ${ }^{(3-4)}$.

The checklist presented succinctly and specifically refers to children's preoperative period, which makes its use more feasible as it is not long to complete. Thus, the proposed instrument only highlights those aspects that are relevant and capable of follow-up by children and families.

One of the most important causes of anxiety is related to the fear of the unknown, especially during the time prior to the surgery, and children may have dramatic reactions ${ }^{(20)}$. With this in mind, the preparation of children and their families for surgery has been the subject of study for many years, with the purpose of reducing the stress and harmful consequences of hospitalization, such as developmental regression, aggressive or depressive behavior and consequent trauma(21-22).

The WHO campaign "Patient to Patient Safety" shows the importance of patients' participation in their own care and has turned into one of the recommended priorities in healthcare institutions; however, many factors can hinder the participation of patients, for example the reluctance on the part of healthcare professionals ${ }^{(23-25)}$

The collaborative work between staff, patients and families promotes safer care, reduces children's anxiety and increases the satisfaction of patients and families. Thus, the use of this type of instrument can be a tool for interaction between professionals, children and families.

Data showing the results of this involvement is rare in the literature, but there is a need for healthcare professionals to understand how patients can be involved in care $^{(26)}$.

With this in mind, the healthcare institutions can implement guidelines to promote interdisciplinary and collaborative work, in order to achieve patient safety and improve health quality, thus encouraging the development of a safety culture related to the children's hospitalization process ${ }^{(27)}$.

In order to consolidate the results obtained in the present investigation, the next step will be the clinical validation of the checklist.

\section{Limitation of the study}

This study will be expanded through the clinical validation of the instrument, aimed at evaluating its acceptance and use by children and families. This aspect of the research is in the data collection stage and might bring evidence that shows the specificity of the instrument.

\section{Conclusion}

When submitted to a group of specialists, the checklist was considered validated after two applications 
of the Delphi technique. The checklist appears as a tool capable of contributing to the accomplishment of some important preoperative preparation stages, also being capable of supporting the provision of information to patients and families concerning their importance in the care process, and also allowing the healthcare team to check the performance of activities. Therefore, the checklist can be used as a tool to promote patient safety.

\section{References}

1. World Health Organization (WHO). A World Alliance for Safer Health Care. More Than Words: Conceptual Framework for the International Classification for Patient Safety. Version 1.1. Final Technical Report. Geneva (Switzerland): World Health Organization; 2009.

2. Runciman $W$, Hibbert $P$, Thomson R, Schaaf TVD, Sherman $H$, Lewalle P. Towards an international classification for patient safety: key concepts and terms. Qual Health Care. 2009;21(1):18-26.

3. Weiser TG, Berry WR. Review article: Perioperative checklist methodologies. Can J Anesth. 2013; 60(2):136-42.

4. Vats A, Nagpal K, Moorthy K. Surgery: a risky business. J Perioper Pract. 2009; 19(10):330-4.

5. World Health Organization. The second global patient safety challenge: safe surgery saves lives. [internet] 2009. [acesso 25 maio 2013]. Disponível em: http:// www.who.int/patientsafety/safesurgery/knowledge_ base/SSSL_Brochure_finalJun08.pdf

6. Broering CV, Crepaldi MA. Preparação psicológica e o estresse de crianças submetidas a cirurgias. Psicol Estudo. 2011;16(1):15-23.

7. Martinez EA, Tocantins FR, Souza SR. As especificidades da comunicação na assistência de enfermagem à criança. Rev Gaucha Enferm. 2013;34(1):37-44.

8. Waterman AD, Gallagher TH, Garbutt J, Waterman BM, Fraser V, Burroughs TE. Brief report: hospitalized patients' attitudes about and participation in error prevention. J Gen Intern Med. 2006;21:367-70.

9. Silva T, Wegner W, Pedro ENR. Segurança da criança hospitalizada na UTI: compreendendo os eventos adversos sob a ótica do acompanhante. Rev Eletr Enferm. [Internet]; 2012; [acesso 25 maio 2013]. 14(2):33744. Disponível em: http://dx.doi.org/10.5216/ree. v14i2.12977

10. Murakami R, Campos CJG. Importância da relação interpessoal do enfermeiro com a família de crianças hospitalizadas. Rev Bras Enferm. 2011;64(2):254-60.
11. Martins GA, Theóphilo CR. Metodologia da investigação científica para ciências sociais aplicadas. $2^{a}$ ed. São Paulo: Editora Atlas; 2009.

12. LoBiondo-Wood G, Haber J. Pesquisa em Enfermagem: Métodos, Avaliação Crítica e Utilização. $4^{a}$ ed. Rio de Janeiro: Editora Guanabara e Koogan; 2001. 13. Perroca MG. Desarrollo y validación de contenido de la nueva versión de un instrumento para clasificación de pacientes. Rev. Latino-Am. Enfermagem. 2011; 19(1):58-66.

14. World Health Organization (WHO). World Alliance for Patient Safety. Forward Program 2008-2009. [Internet]. Geneva (SZ): World Health Organization; 2008. [acesso 26 maio 2013]. Disponível em: http://www.who.int/ patientsafety/information_centre/reports/Alliance_ Forward_Programme_2008.pdf

15. Jha AK, Prasopa-Plaizier N, Larizgoitia I, Bates DW. Patient safety research: an overview of the global evidence. Qual Saf Health Care. 2010;19(1):42-7.

16. World Health Organization (WHO). World Alliance for Patient Safety. Patient safety workshop: learning from error. Geneva (SZ): World Health Organization; 2010.

17. Wegner W, Pedro ENR. Patient safety in care circumstances: prevention of adverse events in the hospitalization of children. Rev. Latino-Am. Enfermagem. 2012;20(3):427-34

18. Quirino DDE, Collet N, Neves AFGB. Hospitalização infantil: concepções da enfermagem acerca da mãe acompanhante. Rev Gaucha Enferm. 2010;31(2):300-6. 19. Araujo YB, Collet N, Moura FM, Nóbrega RD. Conhecimento da família acerca da condição crônica na infância. Texto Contexto Enferm. 2009;18(3):498-505. 20. Fighera, J, Viero E. Vivências do paciente com relação ao procedimento cirúrgico: fantasias e sentimentos mais presentes. Rev SBPH. 2005;8(2):51-63.

21. Sampaio CEP, Ventura DSO, Batista IF, Antunes TCS. Sentimentos dos acompanhantes de crianças submetidas a procedimentos cirúrgicos: vivências no perioperatório. REME: Rev Min Enferm. 2009; 13(4):558-64.

22. Melo WA, Marcon SS, Uchimura TT. A hospitalização de crianças na perspectiva de seus acompanhantes. Rev Enferm UERJ. 2010; 18(4):565-71.

23. Souza LD, Gomes GC, Santos CP. Percepções da equipe de enfermagem acerca da importância da presença do familiar/acompanhante no hospital. Rev Enferm UERJ. 2009; 17(3):394-9.

24. Strasburg AC, Pintanel AC, Gomes GC, Mota MS. Cuidado de enfermagem a crianças hospitalizadas: percepção de mães acompanhantes. Rev Enferm UERJ. 2011; 19(2):262-7. 
25. Mendes MGSR, Martins MMFPS. Parceria nos cuidados de enfermagem em pediatria: do discurso à ação dos enfermeiros. Rev Enferm Ref. [Internet]. 2012; [acesso 18 maio 2013];3(6):113-21. Disponível em: http:// www.scielo.oces.mctes.pt/scielo.php?pid=S087402832012000100011\&script $=$ sci_arttext\&tIng=pt

26. Schatkoski AM, Wegner W, Algeri S, Pedro ENR. Nursing process: from literature to practice. What are we actually doing? Rev. Latino-Am. Enfermagem. 2009;17(3):410-6.

27. Smith JR, Cole FS. Patient safety: effective interdisciplinary teamwork through simulation and debriefing in the neonatal ICU. Crit Care Nurs Clin N Am. 2009; 21(2):163-79. 